УДК 342.95

DOI https: / / doi.org/10.32837 / yuv.v0i3.1937

\author{
Р. Пилипів, \\ кандидат юридичних наук, \\ доцент кафедри «Право» \\ Івано-Франківської філії \\ Відкритого міжнародного університету розвитку людини «Україна»

\section{А. Тимчишин,} \\ кандидат юридичних наук, доцент, \\ завідувач кафедри «Право» \\ Івано-Франківської філії \\ Відкритого міжнародного університету розвитку людини «Україна»
}

\title{
АДМІНІСТРАТИВНА ВІДПОВІДАЛЬНІСТЬ ЗА ПОРУШЕННЯ ПРАВИЛ ЩОДО КАРАНТИНУ ЛЮДЕЙ: ПРОБЛЕМИ ТА ПЕРСПЕКТИВИ
}

У 2020 році ми є свідками та учасниками наймасштабнішого світового захворювання XXI століття - пандеміï коронавірусу (SARS COVID-19). Моніторинг статистики захворюваності та смертності від COVID-19 дає підстави для більшості країн світу зрозуміти, що подолання такого кризового моменту вимагає від влади запровадження дієвих заходів превентивного та реабілітаційного характеру. Щоб запобігти поширенню коронавірусної хвороби, у багатьох державах було запроваджено жорсткі карантинні заходи, й Україна не стала винятком. У нашій державі було прийнято низку нормативно-правових актів, націлених на впровадження карантинних заходів та встановлення відповідальності за порушення правил, спрямованих на запобігання поширенню інфекційних хвороб.

Пандемія коронавірусу вплинула на соціальну, політичну та, безумовно, економічну системи нашої держави. Більш за все умови карантину позначилися на житті простих людей. Вони сильніше відчули на собі бар'єри ізоляції, а їхні законні права, надані Конституцією України, обмежилися.
Досить багато питань виникає стосовно практичного застосування і тлумачення нових «карантинних» норм щодо самоізоляції, соціальної дистанції та «маскового» режиму, адже їх ефективність залежить від свідомого ставлення кожного громадянина. Для того щоб це ставлення було більш ефективним, Верховна Рада України встановила адміністративну відповідальність за порушення протиепідемічних заходів.

Адміністративна відповідальність завжди перебуває у площині уваги науковців. Вихідні теоретичні засади цього інституту адміністративного права набули розвитку у наукових працях Л.Р. Білої-Тіунової, Ю.П. Битяка, P.A. Калюжного, С.В. Ківалова, В.К. Колпакова, А.Т. Комзюка, В.А. Крижановської, Д.М. Лук'янця, О.В. Негодченка, О.Л. Чернецького та інших поважних учених. Сьогодні вірусна пандемія викликала небезпідставний інтерес до адміністративної відповідальності за порушення норм карантинного режиму. Серед останніх здобутків із цього питання можна навести публікації А.А. Вознюка та С.С. Чернявського [1], С.M. Козіна та Я.І. Роговської [2], М.Ю. Гаврилюк 
та А.В. Погорілецької [3] та ін. Окрім того, у контексті нашого дослідження окрему увагу ми приділяємо аспекту звільнення від адміністративної відповідальності через малозначність правопорушень. Із боку теорії це питання розглядалося чи згадувалося у наукових працях М.Ю. Веселова [4], О.3. Гладуна [5], С.О. Рєзніка [6], Л.В. Шестака [7] тощо. Водночас у межах практики правового врегулювання та застосування інституту адміністративної відповідальності за порушення карантинних правил дотепер залишається чимало проблем, вирішення яких потребує наукового підходу.

Метою цієї статті є аналіз практики застосування адміністративної відповідальності за порушення правил щодо карантину людей у сучасних умовах та напрацювання перспектив удосконалення цього інституту в зазначеній сфері. У межах предмета нашого дослідження суміжним завданням $є$ з'ясування особливостей застосування інституту звільнення від адміністративної відповідальності через малозначність правопорушення у справах за ст. 44-3 Кодексу України про адміністративні правопорушення (далі - КУпАП).

Постановою Кабінету Міністрів України від 11.03.2020 № 211 «Про запобігання поширенню територією України гострої респіраторної хвороби COVID-19, спричиненої коронавірусом SARS-Cov-2» з березня поточного року на всій території України було проголошено карантин, який згодом було подовжено. Велика кількість українців вимушена була ізолюватися у своїх домівках для своєї безпеки, безпеки своїх родичів та суспільної безпеки. Ці та інші карантинні заходи сприяли стримуванню поширення (в геометричній прогресіі) випадків захворювань населення України. Робота Національної поліції, Національної гвардії та деяких інших державних установ була зорієнтована на контроль виконання карантинних норм фізичними та юридичними особами, реагування на факти порушень, зокрема оформлення відповідних матеріалів для притягнення винних осіб до адміністративної відповідальності. Проте практика прийняття судових рішень та притягнення таких осіб до адміністративної відповідальності не є такою однозначною.

Законом України «Про внесення змін до деяких законодавчих актів України, спрямованих на запобігання виникненню i поширенню коронавірусної хвороби (COVID-19)» від 17.03.2020 № 530 КУпАП було доповнено ст. 44-3 «Порушення правил щодо карантину людей». Цією нормою було встановлено адміністративну відповідальність за порушення правил, спрямованих на запобігання поширенню COVID-19.

Станом на 06.04.2020 до Єдиного державного реєстру судових рішень було внесено 402 постанови судів про притягнення осіб до адміністративної відповідальності за скоєння правопорушень, передбачених зазначеною статтею КУпАП. На нашу думку, це лише крапля у морі порівняно 3 кількістю фактичних порушень різних карантинних правил, які мали місце з боку наших співвітчизників за цей період. Водночас аналіз судових рішень за цими матеріалами вказує на наявність ще більших проблем. По-перше, з числа цих матеріалів про адміністративні правопорушення більше ніж у $79 \%$ випадків провадження у справі щодо особи за ст. 44-3 КУпАП було закрито у зв'язку з відсутню складу чи події адміністративного правопорушення або повернуто до підрозділів поліції для доопрацювання, оскільки протоколи про адміністративне правопорушення не відповідали вимогам ст. 256 КУпАП. Із тих матеріалів, що залишилися, $20,2 \%$ проваджень було закрито постановами суду у зв'язку 3 малозначністю скоєного правопорушення: суд обмежився лише усним зауваженням, закривши провадження 
в справі. I лише близько $8 \%$ осіб від загальної кількості оформлених порушень було визнано винними у скоєнні адміністративного правопорушення, передбаченого ст. 44-3 КУПАП, і притягнуто до реальної адміністративної відповідальності [8].

Тож серед наведених рішень судів спостерігається тенденція закривати провадження за малозначністю адміністративного правопорушення. Нагадаємо, що санкція ст. 44-3 КУПАП тягне за собою накладення штрафу на громадян від 1 до 2 тис неоподатковуваних мінімумів доходів громадян і на посадових осіб - від 2 до 10 тис неоподатковуваних мінімумів доходів громадян (фактично мінімальний штраф 17 тис грн). Це дуже значна сума як для пересічного українця. Але навіть якщо це так, чи достатньо лише обмежуватися усним зауваженням? Адже цілком логічно буде вважати, що значна сума штрафу $€$ сумірною розміру можливої суспільної шкоди правопорушення, навіть із формальним складом. Це питання залишається актуальним дотепер, 3 огляду на те, що Міністерство охорони здоров'я України (в умовах послаблення карантину) анонсує щоденне збільшення цифр заражених вірусом COVID-19 (станом на 26.06.2020 в Україні інфіковано понад 41,1 тис осіб, +1 109 випадків за добу; 1086 осіб померло), а нехтування правилами карантину українцми помітно зростає.

Можливість звільнення від адміністративної відповідальності за малозначності правопорушення передбачається положеннями ст. 22 КУпАП. Проте самого поняття та ознак малозначності правопорушення Кодекс не містить. Отже, питання це вирішується 3 огляду на аргументи адвокатів чи правопорушника особисто, за внутрішнім переконанням суддів. Проте відсутність єдиних рамок викликає чимало питань із цього приводу, особливо щодо застосування цього інституту за правопорушення, що передбачені ст. 44-3 КУпАП.

Ст. 22 КУпАП наголошує на тому, що за малозначності вчиненого адміністративного правопорушення орган (посадова особа), уповноважений вирішувати справу, може звільнити порушника від адміністративної відповідальності й обмежитися усним зауваженням. Усне зауваження вважається методом виховного впливу i не пов'язане 3 адміністративним стягненням чи заходом громадського впливу. Воно не спричиняє юридичних наслідків для правопорушника, однак останній, своєю чергою, повинен усвідомлювати протиправність своєї поведінки і не допускати подібного у майбутньому [9].

Л.В. Шестак разом з С.В. Веремієнком зазначали, що звільнення від відповідальності за адміністративне правопорушення $є$ однією з форм виховного впливу, що застосовується органом (посадовою особою) адміністративної юрисдикції. Така форма реагування не пов'язана ні 3 адміністративним стягненням, ні із заходами громадського впливу, оскільки усне зауваження правопорушнику не тягне для останнього жодних юридичних наслідків [7, с. 97]. Досліджуючи це питання на монографічному рівні, С.О. Рєзнік виявив сучасні підходи до розуміння малозначності діяння, визначив основні ознаки малозначності тощо. Він сформував поняття малозначності правопорушення, а саме це діяння, що хоча й має формальні ознаки адміністративного правопорушення, але є вчиненим із необережності або за обставин, що пом'якшують відповідальність, при цьому не є шкідливим для державного або громадському порядку, за своїм способом учинення та наслідками не завдає або не може завдати фізичним та юридичним особам шкоди розміром вище за передбачену законодавством за таке правопорушення мінімальну санкцію [6]. Проте, як слушно зазначає О.З. Гладун, у кожному конкретному випадку орган (посадова особа), 
уповноважений вирішувати справу, робить висновок про його малозначність на власний розсуд, відповідно до особистих уявлень про перелік правопорушень, що можуть визнаватися малозначними, а також про ознаки, які вказують на малозначність того чи іншого діяння (що не виключає суб'єКтвизму. - Прим. авт.) [5, с. 108]. Таке уявлення співпадає 3 позицією Міністерства юстиції України, яке в Листі від 06.03.2018 № 8887/440833-18/11.2.2 пояснює, що орган (посадова особа), уповноважений розглядати справи про адміністративні правопорушення, звільняє правопорушника від адміністративної відповідальності в кожному випадку окремо, зважаючи на характер учинюваного діяння та обставини справи [10].

Судова практика демонструє, що переважна більшість висновків суддів щодо малозначності діяння грунтується на наявності пом'якшуючих обставин, зокрема беруться до уваги щире каяття правопорушника, вчинення адміністративного правопорушення вперше тощо. Вочевидь, що це такі правопорушення, які не становлять великої суспільної шкоди та не завдають значних збитків як державі, так і суспільству або безпосередньо громадянам [11]. Наприклад, суддя Нікопольського міськрайонного суду Дніпропетровської області звільнив особу від адміністративної відповідальності, передбаченої ч. 1 ст. 41 КУпАП (порушення вимог законодавства про працю та охорону праці), у зв'язку 3 малозначністю діяння, обмежившись усним зауваженням, через те, що особа повністю визнала свою провину та до адміністративної відповідальності притягається вперше [12].

Для того щоб упевнено казати про те, що порушення карантинних правил не завдало шкоди суспільним інтересам, слід напевно знати, що, наприклад, особа, яка не користувалася захисною маскою в громадському місці чи транспорті, не $€$ хворою на COVID-19. Але аналіз судової практики свідчить про те, що подібні факти на час розгляду справи про адміністративні правопорушення, передбачені ст. 44-3 КУПАП, не встановлювалися. При цьому людина, яка порушує те чи інше правило, не може бути впевнена в тому, що вона не $€$ носієм хвороби.

Причина збільшення кількості захворювань, а також подібне звільнення від адміністративної відповідальності наштовхують на роздуми про те, чи буде доцільним застосовувати й надалі інститут малозначності у провадженнях за ст. 44-3 КУпАП та чи не спровокує це ще більше нехтування нормами та правилами карантину. Розглянемо простий приклад: особа без одягнутої на обличчя маски відвідує громадське місце у період карантину та не дотримується при цьому соціальної дистанції. İi зупиняють співробітники поліції та складають проти неї адміністративний протокол про порушення правил щодо карантину людей. У протоколі зазначають причину і умови правопорушення, справа передається до суду, який у подальшому звільняє особу від відповідальності через нібито малозначність діяння у зв'язку з визнанням особою вини, дійовим каяттям, учиненням адміністративного правопорушення вперше та незначним матеріальним статком його родини. Чи навчить це особу дотримуватися законодавства надалі? $€$ два варіанти: перший у подальшому ця особа не буде ігнорувати правила карантину, подібних правопорушень не повторить, другий - у подальшому ця особа стане не тільки порушником формальних правил, а й імовірним поширювачем коронавірусу. При цьому той факт, що це буде відбуватися ненавмисно, не зменшить суспільної шкоди від таких дій (бездіяльності).

Диспозиція ст. 44-3 КУПАП є банкетною, отже, адміністративна відповідальність може настати за порушення будь-яких рішень органів місцевого 
самоврядування, якими передбачено заходи боротьби з інфекційними хворобами. Тому ми пропонуємо дещо диференціювати цю статтю шляхом розділення іï на декілька частин із різними санкціями. Такий процес подрібнення дасть змогу більш визначено давати правову оцінку порушенню того чи іншого правила. Першу частину ст. 44-3 пропонуємо викласти у такій редакціі: «Порушення маскового режиму та социіальної дистанції громадянами в період карантину тягне за собою ...», частину другу: «Порушення правил обсервації та самоізоляиії в період карантину тягне за собою ...», частину третю: «Порушення правил щзодо карантину людей крім тих, щзо передбачені у частині першій та другій, а також санітарно-гігієнічних, санітарно-протиепідемічних правил і норм, передбачених законами України та іншими нормативно правовими актами тягне за собою ...». Санкції у перших двох частинах мають бути «відчутними» для громадян, щоб забезпечити належне виконання (дотримання) ними охоронюваних законом правил, але нижчими, ніж у частині третій.

Таким чином, інститут звільнення від відповідальності у зв'язку 3 малозначністю правопорушення в адміністративному праві не має чітких меж, а також умов та обставин для його застосування. Його застосування не $€$ винятком, проте прийняття рішення про звільнення особи від адміністративної відповідальності через малозначність у провадженнях за ст. 44-3 КУпАП є проблематичним. По-перше, через те, що законодавець не дає визначення малозначного правопорушення; по-друге, не називає його ознак; по-третє, у законодавстві немає точного переліку малозначних правопорушень; по-четверте, визначити реальні наслідки порушень карантинних правил, що стали об’єктом адміністративного делікту, у стислі терміни розгляду судом таких проваджень становить практичні труднощі.
Звільнення особи від адміністративної відповідальності у зв'язку 3 малозначністю правопорушення не є обов'язком юрисдикційного органу, посадової особи. У момент прийняття рішення про звільнення такий орган чи особа повинні розглянути і проаналізувати всі моменти вчиненого порушення, оцінити обстановку його здійснення, його наслідки, переконатися, що відсутня значна шкода. Окрім цього, враховувати особу правопорушника, ступінь його вини, характер правопорушення, а також обставини, що обтяжують чи пом'якшують відповідальність, тощо [11].

Ми вважаємо, що застосування інституту звільнення від відповідальності у зв'язку з малозначністю правопорушення у разі порушення карантинних норм є дещо недоцільним і має носити лише винятковий характер, а тому пропонуємо раціонально вдосконалити зміст ст. 44-3 КУпАП, а саме розбити ї на декілька частин із можливістю диференціації диспозицій та санкцій за ступенем можливості спричинення шкоди суспільним чи державним інтересам або громадянам, ймовірності негативного впливу на епідеміологічну ситуацію в країні. Це надасть динамічності та реальної дієвості вказаним нормам, що змусить громадян сумлінно дотримуватися карантинних обмежень. Перспективним у цьому руслі дослідження видається визначення адекватних заходів реагування (санкцій) за ці правопорушення, що стане предметом наших подальших наукових розвідок.

У статті досліджено національне законодавство Украӥни про адміністративну відповідальність за порушення правил щзодо карантину людей. Проаналізовано практику розгляду судами справ про притягнення осіб до адміністративної відповідальності за скоєння правопорушень, передбачених ст. 44-3 КУпАП у сучасних умовах. Установлено, шзо серед підстав для закриття провадження за порушення правил щодо 
карантину людей у судах спостерігається тенденція закривати такі провадження за малозначністю адміністративного правопорушення. Підкреслено, що самого поняття та ознак малозначності правопорушення чинне українське адміністративно-деліктне законодавство не містить. Не додають иілковитої визначеності цьому питанню $і$ наявні у правовій науці теоретичні роботи. Судова практика демонструє, що переванна більшість висновків суддів щодо малозначності діяння трунтуеться на наявності пом'якшуючих обставин, зокрема беруться до уваги щире каяття правопорушника, вчинення адміністративного правопорушення вперше, характер скоєного діяння та обставини справи тощо. Наголошується, що визначити реальні наслідки порушень карантинних правил, що стали об'єктом адміністративного делікту, у стислі терміни розгляду судом таких проваджень $\epsilon$ складним процесом. Це призводить до формалізму та суб'єктивізму у прийнятті таких рішень $і$ як побічний ефект може викликати нехтування нормами карантину з боку населення. Робиться висновок, що застосування інституту звільнення від відповідальності у зв'язку з малозначністю правопорушення у разі порушення карантинних норм $\epsilon$ дещо недоцільним. Натомість пропонується раціонально вдосконалити зміст cm. 44-3 КУпАП, а саме розбити ї на декілька частин із можливістю диференціації диспозицій та санкцій за ступенем можливості спричинення шкоди суспільним чи державним інтересам або громадянам, імовірності негативного впливу на епідеміологічну ситуацію в країні.

Ключові слова: адміністративна відповідальність, звільнення від відповідальності, карантин, коронавірус, малозначність адміністративного правопорушення.

\section{Pylypiv R., Tymchyshyn A. Administrative liability for violation of human quarantine rules: problems and prospects}

The article examines the national legislation of Ukraine on administrative liability for violating the rules on quarantine of people. The practice of consideration by courts of cases on bringing persons to administrative responsibility for committing offenses under Art. 44-3 KУnAП in modern conditions. It is established that among the grounds for closing the proceedings for violation of the rules on quarantine of people, there is a tendency in the courts to close such proceedings for the insignificance of an administrative offense. It is emphasized that the current Ukrainian administrative-tort legislation does not contain the very concept and signs of insignificance of the offense. Theoretical works available in legal science do not add complete certainty to this question. Judicial practice shows that the vast majority of judges' conclusions on the insignificance of the act are based on mitigating circumstances, in particular, taking into account the offender's sincere remorse, committing an administrative offense for the first time, the nature of the act and the circumstances of the case. It is emphasized that it is a difficult process to determine the real consequences of violations of quarantine rules that have become the subject of an administrative tort in a short time. This leads to formalism and subjectivity in making such decisions and, as a side effect, can lead to disregard for quarantine by the population. It is concluded that the use of the institution of exemption from liability due to the insignificance of the offense in case of violation of quarantine rules is somewhat impractical. Instead, it is proposed to rationally improve the content of Article 44-3 of the Code 
of Administrative Offenses, namely to divide it into several parts, with the possibility of differentiating dispositions and sanctions according to the degree of harm to public or state interests or citizens, the likelihood of negative impact on the epidemiological situation.

Key words: administrative liability, release from liability, quarantine, coronavirus, insignificance of an administrative offense.

\section{Література}

1. Вознюк А.А., Чернявський С.С. Порушення правил $і$ норм щодо запобігання COVID-19: актуальні проблеми кримінальної та адміністративної відповідальності. Юридичний часопис Національної академії внутрішніх справ. 2020. № 1(19). С. 8-19.

2. Роговська Я.I., Козін С.М. Штрафи та адміністративна відповідальність при порущенні умов карантину. Збірник наукових праць АОГОЕ. 2020. С. 82-83. URL: ojs.ukrlogos.in.ua (дата звернення: 01.07.2020)

3. Гаврилюк М.Ю., Погорілецька А.В., Веселов М.Ю. Права та обов'язки працівників Національної поліції в умовах карантину. Національна поліція Украіни: сучаснии стан та перспективи розвитку : матеріали III Всеукраїнськоі науково-практичної конференції, м. Кривий Ріг, 24 квітня 2020 р. Кривий Ріг : ДЮІ МВС України, 2020. С. 26-29.

4. Веселов М.Ю. Звільненя неповнолітніх від адміністративної відповідальності. Національна поліція Украіни: сучасний стан та перспективи розвитку : матеріали III Всеукраїнської науково-практичної конференції, м. Кривий Ріг, 24 квітня 2020 р. Кривий Ріг : ДЮІ МВС України, 2020. С. 51-52.

5. Гладун О.3. Малозначність кримінальних $і$ адміністративних корупційних правопорушень. Боротьба з організованою злочинністю $i$ корупиією (теорія $i$ практика). 2012. № 2(28). C. 103-112.
6. Рєзнік С.О. Малозначність правопорушення як підстава звільнення від адміністративної відповідальності : дис. ... канд. юрид. наук : 12.00.07. Дніпропетровськ, 2011. $280 \mathrm{c}$.

7. Шестак Л.В., Веремієнко С.В. До питання про звільнення від адміністративної відповідальності за незначне правопорушення. Науковий вісник Ужгородського наиіонального університету. Серія «Право». 2015. Bun. 30. T. 2. C. 96-98. URL: http: / / www.visnyk-juris.uzhnu.uz.ua / file/No.30/part_2/26.pdf (dama звернення: 20.08.2017).

8. Ореховський М.Л. Аналіз постанов по 44-3 КУпАП - Судді в 90\% випадків відмовляються итрафувати українців за порушення правил карантину. 08.04.2020. URL: https: / / protocol.ua / ru / analiz_postanov_ po_44_3_kupap_suddi_v_90_vipadkiv_ vidmovlyayutsya_shtrafuvati_ukraintsiv_ za_porushennya_pravil_karantinu) (Jama звернення: 22.06.2020).

9. Науково-практичнии коментар Кодексу України про адміністративні правопорушення / P.А. Калюжний та ін. Kuїв : Правова єдність, 2008. 781 c.

10. Щодо надання роз'яснення поняття малозначності вчиненого правопорушення : Лист Міністерства юотииії України від 06.03.2018 № 8887 / 4408-33-18/11.2.2. URL: https: / / zakon.help / article/shchodo-nadannyarozyasnennya-ponyattya-maloznachnosti/ (дата звернення: 22.06.2020).

11. Малозначні правопорушення: Вознесенським міськрайонним судом Миколаївської області узагальнено практику за перше півріччя 2018 року: архів новин. Судова влада України. URL : https:// ics.gov.ua/archive/528126/ (дата звернення: 22.06.2020).

12. Постанова судді Нікопольського міськрайонного суду Дніпропетровської області від 27.01.2017 у справі № 182/191/17. Провадження № 3/0182/131/2017. URL: $\quad$ https://protocol.ua/ua/sud_ maloznachnist_diyannya_abo_zvilnennya_vid_ adminvidpovidalnosti_za_nepovidomlennya_ dfs_pro_priynyattya_na_robotu/ (dama звернення: 22.06.2020). 